\title{
Audit of Electricity Generation in University of Lagos, Nigeria
}

\author{
Oluwatosin M. Dada ${ }^{1,}$, Ilesanmi A. Daniyan ${ }^{1}$, Temitayo M. Azeez ${ }^{1}$, Olalekan O. Adaramola ${ }^{2}$ \\ ${ }^{1}$ Department of Mechanical and Mechatronics Engineering, Afe Babalola University, Ado Ekiti, Nigeria \\ ${ }^{2}$ Department of Computer Engineering, Afe Babalola University, Ado Ekiti, Nigeria
}

Email address:

tossydada@yahoo.co.uk (O. M. Dada)

${ }^{*}$ Corresponding author

\section{To cite this article:}

Oluwatosin M. Dada, Ilesanmi. A. Daniyan, Temitayo M. Azeez, Olalekan O. Adaramola. Audit of Electricity Generation in University of Lagos, Nigeria. International Journal of Energy and Power Engineering. Vol. 5, No. 2, 2016, pp. 29-33. doi: 10.11648/j.ijepe.20160502.11

Received: November 18, 2015; Accepted: November 29, 2015; Published: March 21, 2016

\begin{abstract}
Electricity is indispensable to a nation's economic development. In this paper, analysis of energy sources was carried out to ascertain their costs. The selected energy alternatives are PHCN $132 \mathrm{kV} / 33 \mathrm{kV} / 11 \mathrm{kV}$ Substation and Captive Cummings Diesel generator. The case study-site was University of Lagos, Akoka located within Lagos, a commercial city in Nigeria. Practical surveys and data collection were carried out from the power house coupled with their load estimation to obtain the total cost of electricity consumed. The results indicate that, on a monthly basis, the university spends about $\$ 820,000$ on diesel generator and $\$ 228,500$ on PHCN.The results also show that other alternative energy sources should be included in the overall energy mix in order to minimise the total power cost of the university.
\end{abstract}

Keywords: Energy Consumption (kWh), Peak Load (kW), Base Load (kW), Cost Per kWh

\section{Introduction}

Electricity is indispensable to a nation's economic development as it drives industrialization, technology advancement and standard of living of the people. Over the past two decades, the stalled expansion of Nigeria's grid capacity, combined with the high cost of diesel and petrol, has crippled the growth of the country's productive and commercial industries. Nigeria's per capita electricity consumption is amongst the lowest in the world and far lower than many other African countries. Nigeria's per capita electricity consumption is just $7 \%$ of Brazil's and just $3 \%$ of South Africa's. Brazil has 100,000 MW of grid-based generating capacity for a population of 201 million people. South Africa has 40,000 MW of grid-based generating capacity for a population of 50 million people. Nigeria, with a population of over 150 million people has a peak generation of only 3804 MW (The Presidency, 2010). Nigeria's electricity crisis significantly undermined the effort to achieve the sustained economic growth, competitiveness in regional and global markets, employment generation and poverty alleviation. The prolonged dismal electricity industry performance has been the most intractable infrastructural problem and policy challenge in the last half a century (Iwayemi, 2008). Electricity generation in Nigeria is characterized by excess capacity and inadequate supply. It has been observed that peak power generation is often about one-third of installed capacity due to the non-availability of spare parts and poor maintenance. A poorly-motivated workforce, vandalisation and theft of cables and other vital equipment, accidental destruction of distribution lines, illegal connections and resultant over-loading of distribution lines, are additional major problems of the electricity sector. These have been responsible for unannounced load shedding, prolonged and intermittent outages which most consumers of electricity in Nigeria have had to contend with over the years. The efficiency of the supply of electricity will not only influence returns on investment in existing enterprises, it also plays a major role in the creation of an economic environment which influences decisions on potential investments. The electric power sub-sector in Nigeria, dominated by the Power Holding Company of Nigeria (PHCN), has been unable to provide and maintain 
acceptable minimum standards of service reliability, accessibility and availability (Adesiji, 2009). However, the University of Lagos located in Akoka, Lagos also experiences shortage in electricity supply, of which the diesel generator is used to complement it. The main campus has various options for electricity generation; PHCN 132 $\mathrm{kV} / 33 \mathrm{kV} / 11 \mathrm{kV}$ Substation, Captive Cummings Diesel generator, Solar cells and battery-powered inverter used in some faculties and departments (Unilag, Works and Physical Planning Department, 2012)). The first two are highly used to power most of load requirement on campus. The generator is used to power the electrical load and is sometimes complemented with PHCN.

\section{Overview of Electricity Generation in Nigeria}

Electricity plays a very important role in the socioeconomic and technological development of every nation. The electricity demand in Nigeria far outstrips the supply and the supply is epileptic in nature. The country is faced with acute electricity problems, which is hindering its development. The electricity development in Nigeria can be traced back in 1898 when the first generating power plant was installed in Marina Lagos with a total capacity of 60 $\mathrm{kW}$. The Electricity Corporation of Nigeria (ECN) was established by the Colonial Government under the ordinance no. 15 of 1950 to take over the various electricity supplies in the country (Awosope, 2014). In 1962, Act of Parliament established the Niger Dams Authority (NDA) for the development of Hydro Electric Power. However, a merger of the ECN and NDA was made in 1972 to form the National Electric power Authority (NEPA), which as a result of unbundling and the power reform process, was renamed Power holding Company of Nigeria (PHCN) in 2005 (Titus et al., 2012). The Electricity Power Sector Reform (EPSR) Act 2005 translated NEPA into the newly incorporated Power Holding Company of Nigeria (PHCN) comprising of 18 separate successor companies that took over the assets, liabilities and employees of NEPA, and responsible for the generation (6 companies), transmission (a company) and distribution (11 companies) (Okafor, 2005). The EPSR Act set the pace for power privatization in Nigeria. As part of the reform process, a regulatory agency, Nigerian Electricity Regulatory Commission (NERC) was inaugurated in November, 2005. The functions of the NERC were to regulate tariffs, provide quality service, and oversee the electricity industry effectively. This led to the new tariff regime that took effect through a Multi-Year Tariff Order (MYTO) in 2008. The National Electricity Power Policy (NEPP) and the Electric Power Sector Reform Act 2005 (EPSR) provide for the development of Nigeria electricity market (Makwe et al., 2012). Wholesale competition was recommended for Nigeria to assist in monopoly control and cost insensitivity. Thus, the reforms broke NEPA's monopoly and paved the way for the entry of independent power producers (IPPs). Before the reform, tariffs in the Nigerian electricity industry were depressed by government order. The old NEPA was barred by decree from increasing tariffs, even when the cost of supply of electricity had increased. The result was underproduction of electricity and the absence of investment in the network. The EPSR Act 2005 isolated the NERC from the direct control of the government bureaucracy. Nigeria now has a cost reflective tariff, with voluminous traffic in foreign and local investment in the electricity market (Ajumogobia, 2015).

\section{Electricity Supply Infrastructure in University of Lagos}

The University of Lagos located in Akoka, Lagos experiences shortage in electricity supply, of which the diesel generator is used to complement it. The main campus has various options for electricity generation; PHCN $132 \mathrm{kV} / 33$ $\mathrm{kV} / 11 \mathrm{kV}$ Substation, Captive Cummings Diesel generator, Solar cells and battery-powered inverter used in some faculties and departments (Unilag, Works and Physical Planning Department, 2012). The first two are highly used to power most of load requirement on campus. The generator is used to power the electrical load and is sometimes complemented with PHCN. The Power Holding Company of Nigeria (PHCN) supplies the University of Lagos a $11 \mathrm{kV}$ voltage level distribution line from its $132 / 33 / 11 \mathrm{kV}$ station located close to the University's control room panels. Power distribution on campus is effected by means of Ring main system arranged in four (4) rings comprising of eight (8) feeders. Each ring is on a standard cable of $150 \mathrm{~mm} 2 \times 3$ core High Tension Armoured cable which feeds the various sections of the University Community. The total High tension cable network is about 24 kilometers. There are 48 transformer substations with RMU (Ring Mains Units) from where the Low tension distributions are effected to some laboratories, faculties, residential buildings and commercial centers. Peak power requirement of the University is about 9.0 MW (Unilag, Works and Physical Planning Department, 2012). According to the Director of Works and Physical Planning (University of Lagos), Dr. A. E. Adeniran, PHCN charges the University \$3.6 U.S Cents Per kWh of electricity used. The Nigerian Electricity Regulatory Commission (NERC) increased the electricity tariff in the country from $\$ 4.3$ U.S Cents to \$5.0 U.S Cents per kilowatt hour. This was as a result of its implementation of the schedule of the 2008/2013 regime of the Multi- Year Tariff Order (MYTO) (Uwe, 2011). Apart from the cost of power generation by $\mathrm{PHCN}$, the cost of maintaining the generating station is quite expensive.

In March 2010, the University of Lagos and CUMMINS West Africa signed a contract agreement aimed at boosting electricity supply on the University Campuses through the supply and installation of $2 \times 2000 \mathrm{kVA}, 11000$ Voltage Generators at the Power House, Main Campus, Akoka (Unilag, 2010). The two captive Cummings diesel 
generators with the same specification use diesel oil as fuel input. The diesel generator requires regular and preventive maintenance especially for every 250 hours in order to prevent sudden breakdown. The University spends huge amount on diesel monthly to prevent interruption in electricity supply. Strategic plan is currently developed by the University to increase its electrical supply facilities in order to ensure a steady, efficient, uninterrupted supply (Abolarin et al., 2011).
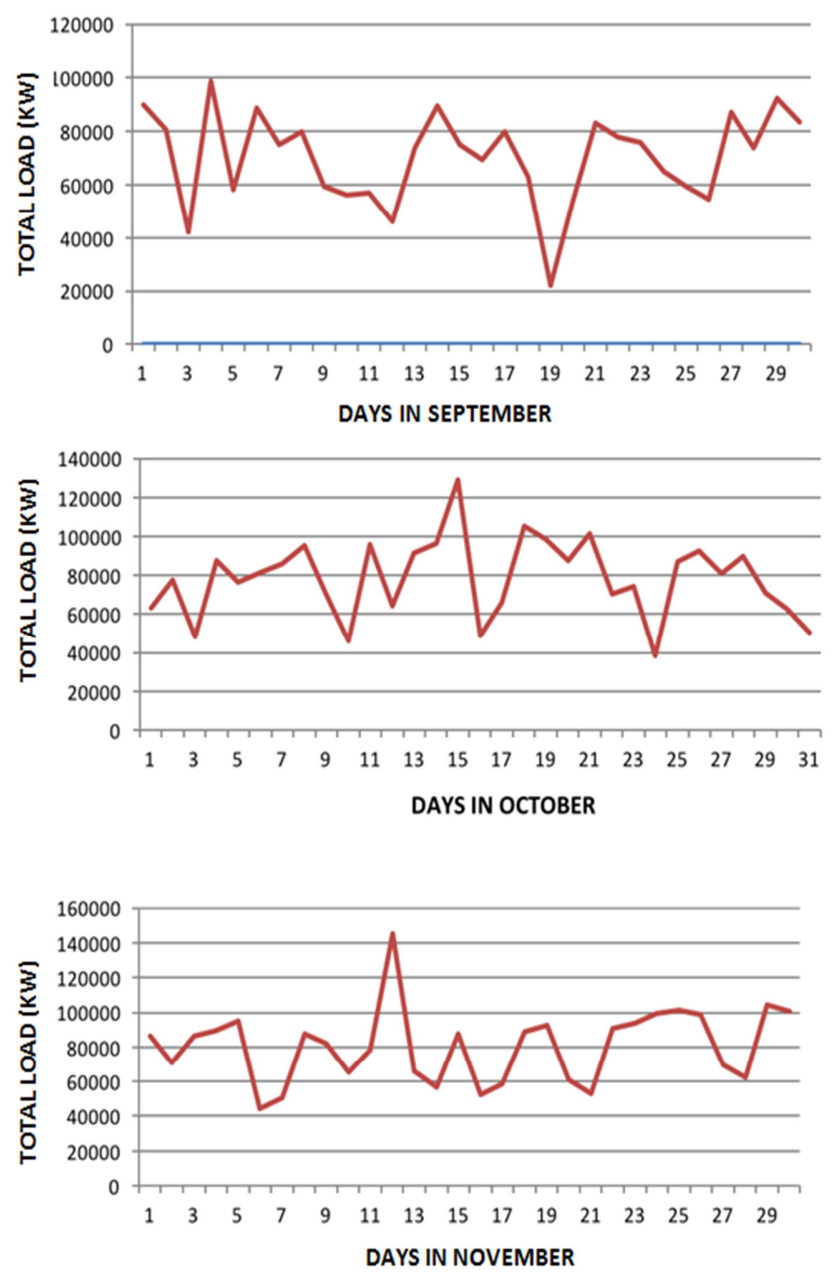

Figure 1. Load Duration Curve from $1^{S T}$ September $2010-30^{T H}$ November 2010.

\section{Results and Discussion}

To analyze the cost of generating electricity, data containing the daily consumption of electricity $(\mathrm{kWh})$ of all the loads on campus was collated at the power plant for six months (1st September 2010 to 28th February 2011) in order to obtain the base load and the peak load and is shown in Figure (1).

The quantity of diesel in liters equivalent to the energy consumed by the loads (base load, peak load) is given as:

$$
\begin{aligned}
& \text { Base load }=\frac{\text { Minimum Daily Energy Consumption }(\mathrm{kWh})}{\text { Duration }(24)} \\
& \text { Peak load }=\frac{\text { Maximum Daily Energy Consumption }(\mathrm{kWh})}{\text { Duration }(24)}
\end{aligned}
$$

The area of the base of the diesel tank $=121.8 \mathrm{~cm} \times 122.5$ $\mathrm{cm}=14920.5 \mathrm{~cm}^{2}$

Volume of the diesel oil used $=$ Area of the base of the tank $X$ Height of the tank

$=14920.5 \times 19.1$

$=284981.55 \mathrm{~cm}^{3}$

$=284.981$ liters

From Table (2), the energy supplied by the generator is $1201 \mathrm{kWh}$

$$
\text { Thus } 1201 \mathrm{kWh}=284.981 \text { liters }
$$

$1 \mathrm{kWh}=284.981 / 1201=0.237$ liters

The mean of the liters per $\mathrm{kWh}$ used by the diesel generator at different time intervals

$$
\begin{aligned}
& =(0.237+0.207+0.226+0.254+0.276) / 5 \\
& =0.240 \text { liters per } \mathrm{kWh}
\end{aligned}
$$

Thus, a diesel generator on campus produces

$$
1 / 0.240=4.167 \mathrm{kWh} \text { per liter }
$$

The lowest monthly base load for the University of Lagos, Akoka campus from September 2010 to February 2011 is $925.83 \mathrm{~kW}$. Also, the highest monthly peak load for the same period is $8804.58 \mathrm{~kW}$ in January 2011 as shown in Table (1).

\begin{tabular}{|c|c|c|c|c|c|c|}
\hline Month/year & $\begin{array}{l}\text { Min. Daily Energy } \\
\text { Consumption (kWh) }\end{array}$ & $\begin{array}{l}\text { Quantity of } \\
\text { diesel (liters) }\end{array}$ & $\begin{array}{l}\text { Base load on } \\
\text { campus }(k W)\end{array}$ & $\begin{array}{l}\text { Max. Daily Energy } \\
\text { Consumption (kWh) }\end{array}$ & $\begin{array}{l}\text { Quantity of } \\
\text { diesel (liters) }\end{array}$ & $\begin{array}{l}\text { Peak load on } \\
\text { campus }(k W) \\
\end{array}$ \\
\hline Sept.2010 & 22,220 & 5332.8 & 925.8 & 98,590 & 23661.6 & 4107.92 \\
\hline Oct.2010 & 38,660 & 9278.4 & 1610.83 & 128,720 & 30892.8 & 5363.33 \\
\hline Nov.2010 & 44,310 & 10634.4 & 1846.25 & 145,320 & 34876.8 & 6055 \\
\hline Dec. 2010 & 30,240 & 7257.6 & 1260 & 96,330 & 23119.2 & 4013.75 \\
\hline Jan.2011 & 33,720 & 8092.8 & 1405 & 211,310 & 50714.4 & 8804.58 \\
\hline Feb.2011 & 29,690 & 7125.6 & 1237.08 & 155,070 & 37216.8 & 6461.25 \\
\hline
\end{tabular}
Thus in order to calculate the quantity of diesel used per $\mathrm{kWh}$, data was collated during the operation of the generator from the power house at the University of Lagos, Akoka. The results are shown in Table $2 \& 3$.

Table 1. Minimum and Maximum daily energy consumption at the University of Lagos, Akoka Campus. 
Table 2. Data collected during operation of a diesel generator at the University of Lagos, Akoka Campus.

\begin{tabular}{|llllll|l|l|l|}
\hline Date & $\begin{array}{l}\text { kWh Reading } \\
\text { (time) }\end{array}$ & $\begin{array}{l}\text { kWh Reading } \\
\text { (time) }\end{array}$ & $\begin{array}{l}\text { kWh supplied by } \\
\text { the generator }\end{array}$ & $\begin{array}{l}\text { Difference in } \\
\text { diesel level } \\
(\mathbf{c m})\end{array}$ & $\begin{array}{l}\text { Volume of diesel } \\
\text { oil used }\left(\mathbf{c m}^{3}\right)\end{array}$ & $\begin{array}{l}\text { Volume used in } \\
\text { liters }\left(\mathbf{c m}^{3} / \mathbf{1 0 0 0}\right)\end{array}$ & $\begin{array}{l}\text { Liters per } \\
\mathbf{k W h}\end{array}$ \\
\hline $31 / 5 / 2011$ & $453549(4 \mathrm{pm})$ & $454750(5 \mathrm{pm})$ & 1201 & 19.1 & 284981.55 & 284.981 & 0.237 \\
$01 / 6 / 2011$ & $528190(1.28 \mathrm{pm})$ & $529105(2: 28 \mathrm{pm})$ & 915 & 12.7 & 189490.35 & 189.490 & 0.207 \\
$01 / 6 / 2011$ & $529105(2.28 \mathrm{pm})$ & $529911(3.28 \mathrm{pm})$ & 806 & 12.2 & 182030.1 & 182.030 & 0.226 \\
$01 / 6 / 2011$ & $530754(3.28 \mathrm{pm})$ & $531507(4.28 \mathrm{pm})$ & 753 & 12.8 & 190982.4 & 190.982 & 0.254 \\
$01 / 6 / 2011$ & $531507(4.28 \mathrm{pm})$ & $532188(5.28 \mathrm{pm})$ & 681 & 12.6 & 187998.3 & 187.9998 & 0.276 \\
\hline
\end{tabular}

Table 3. Estimate of the amount spent on diesel generator from September 2010 - February 2011.

\begin{tabular}{lllll}
\hline Month/Year & Maximum Daily Energy Consumption (kWh) & Quantity of diesel in liters & $\begin{array}{l}\text { Amount (USD) Per } \\
\text { day }\end{array}$ & $\begin{array}{l}\text { Amount (USD) Per } \\
\text { Month }\end{array}$ \\
\hline September 2010 & 98590 & 2366.6 & 19,218 & 576,540 \\
October 2010 & 128720 & 30892.8 & 25,090 & 777,790 \\
November 2010 & 145320 & 34876.8 & 28,326 & 849,780 \\
December 2010 & 96330 & 23199.2 & 18,777 & 582,087 \\
January 2011 & 211310 & 50714.4 & 41,189 & $1,235,670$ \\
February 2011 & 155070 & 37216.8 & 30,226 & 906,805 \\
\hline
\end{tabular}

Table 4. The price of gas to power plants in cents and the corresponding cost per $k W h$ of electricity.

\begin{tabular}{llllllllll}
\hline Price of gas (cents) & $\mathbf{6 4}$ & $\mathbf{7 0}$ & $\mathbf{8 0}$ & $\mathbf{1 0 0}$ & $\mathbf{1 2 0}$ & $\mathbf{1 4 0}$ & $\mathbf{1 6 0}$ & $\mathbf{1 8 0}$ & $\mathbf{2 0 0}$ \\
\hline Electricity cost/kWh (Naira $\mathrm{A})$ & 7.22 & 10.83 & 14.44 & 18.05 & 21.66 & 25.27 & 28.88 & 32.49 & 36.10 \\
\hline
\end{tabular}

Table 5. Cost of electricity for a period (September 2010 - February 2011).

\begin{tabular}{llll}
\hline Month/ Year & Maximum Daily Energy Consumption (KWh) & Amount (USD) Per day & Amount (USD) Per Month \\
September 2010 & 98590 & 5419 & 162,570 \\
October 2010 & 128720 & 7082 & 219,542 \\
November 2010 & 145320 & 7988 & 239,640 \\
December 2010 & 96330 & 5296 & 164,176 \\
January 2011 & 211310 & 11627 & 360,437 \\
February 2011 & 155070 & 8532 & 238,896 \\
\hline
\end{tabular}

The cost per $\mathrm{kWh}$ of electricity provided by the Power Holding Company of Nigeria (PHCN) to the University of Lagos Akoka campus is $\$ 3.6$ U.S Cents in 2011. When the price of gas goes up from 64 cents to $\$ 1.60$, the expected cost per $\mathrm{kWh}$ of electricity provided by the $\mathrm{PHCN}$ will be $\$ 40$ U.S Cents. If the cost of electricity from PHCN is \$54 U.S Cents, the amount to be paid by the University to PHCN is analyzed using the data of the total energy consumed collated from the power house in Table 5. The amount of energy consumed in September increases from $98590 \mathrm{kWh}$ to $145320 \mathrm{kWh}$ in November 2010 and fell drastically to 96330 $\mathrm{kWh}$ in December 2010. The amount the University spends on electricity increases from $\$ 162,570$ in September 2010 to $\$ 239,640$ in November 2010 but fell towards the end of the year to $\$ 164,176$ as a result of decline in energy consumption due to vacation of students and end of the year break. It was observed that the university spend huge amount on diesel generators in Table (3) there is need for alternative option for energy generation in the institution.

\section{Conclusion}

Electricity is the hub of both economic and technological advancement of any nation. The electricity industry in the developing countries has gone through quite a lot of metamorphosis in the recent past. Electricity generation in Nigeria is characterized by slow growth in generation capacity, market deregulation process interference by government, electrical transmission lines and distribution equipment vandalism, poor maintenance of existing electrical facilities and corruption. Nigeria should not be different in the vogue of global electricity market which focuses on building a cleaner, more diverse and more sustainable energy mix. The electricity market investment system should be quality, affordable and of proven security. However, University of Lagos is currently developing strategic plans to increase its physical infrastructure and utilities to ensure a steady, efficient, uninterrupted supply by adopting alternatives means for energy generation. Several ways to 
achieve this include; energy efficiency and conservation in energy audits, setting up committees on energy culture and energy budgeting, incorporation of renewable energy mixes into the present generating capacity. Developing cleaner energy should be part of the investment strategy with the focus on adopting cleaner fossil fuels based on renewable sources to meet the electricity demand in the institution.

\section{References}

[1] Abolarin, M. S., Gbadegesin, A. O., Shitta, B. M and Adegbenro, O. (2011). Energy Lighting Audit of four University of Lagos Hall of Residence. Journal of Engineering Research, Vol. 16, no 2, pp. 1-10.

[2] Adesiji, R. (2009). The Cost of Electricity in Nigeria. The Energy Journal, pp 15.

[3] Ajumogobia \& Okeke (2015). Nigerian Energy Sector: Legal and Regulatory Overview, pp. 13-31.

[4] Awosope, C. A. (2014). Nigeria Electricity Industry: Issues, Challenges and Solution. Public Lecture Series, Vol. 3. No 2, pp. 5-6.

[5] Iwayemi, A. (2008). Investment in Electricity Generation and Transmission in Nigeria: Issues and Option. The Energy Journal, pp 37.
[6] Makwe, J. N., Akinwale, Y. O., and Atoyebi, M. K. (2012). An economic assessment of the reform of Nigerian electricity market. Journal of Energy and Power, Vol. 2. No 3, pp. 24-32.

[7] Okafor F. N. (2005). Modelling the Ancillary Services in Deregulated Power Networks of Developing Economics, 6th International Conference on Power System Operation and Planning (ICPSOP), pp. 222-227.

[8] The Presidency, (2010). Roadmap for Power Sector Reform. A Customer-Driven Sector Wide Plan to achieve Stable Power Supply, pp. 16.

[9] Titus, O. K, Abdul-Ganiyu A. J. and Phillips D. A. (2012). The Current and Future Challenges of Electricity Market in Nigeria in the face of deregulation process, EIE's $2^{\text {nd }}$ Intl' Conf. Comp., Energy, Net., Robotics and Telecom, pp. 30-36.

[10] Unilag. (2010, April 9). Unilag, Cummins sign contract agreement to boast power supply. Retrieved July 31, 2012, from University of Lagos: www.unilag.edu.ng/newsdetailsphp?NewsID $=407$

[11] Unilag. (2012). Works and Physical Planning Department. Retrieved July 30, 2012, from University of Lagos: $\mathrm{http} / /$ www.unilagworks.org/powersupply_n_Distribution.php

[12] Uwe, J. (2011). High Electricity Tarriff: How PHCN Staff short change Nigerians through illegal electricty billing. Retrieved July 31, 2012, from National Mirror: nationalmirroronline.net/index.php/insight/18689.html. 